Article

\title{
The Boomerang Effects: An Analysis of the Pre and Post Dollarisation Era in Zimbabwe
}

\author{
Michael Takudzwa Pasara ${ }^{1, *(D)}$ and Rufaro Garidzirai ${ }^{2}$ \\ 1 Department of Economic Sciences, North West University, Vanderbjilpark 1900, South Africa \\ 2 Department of Management Sciences, Walter Sisulu University, Butterworth 4960, South Africa; \\ rgaridzirai@wsu.ac.za \\ * Correspondence: michaelpasara@gmail.com
}

Received: 18 February 2020; Accepted: 8 April 2020; Published: 17 April 2020

\begin{abstract}
Does dollarisation influence economic activity in Zimbabwe? The question has incited a lot of debates among researchers and analysts. In an attempt to answer this question, the study used an Auto Regressive Distributive Lag (ARDL) procedure, to investigate the effects of dollarisation on economic growth in Zimbabwe. The study employed quarterly data over a 14-year period between 2000 and 2014. The results of the study indicate that dollarisation, gross domestic investment and trade openness are positively related to economic growth. Based on the findings of the study, the paper recommends that Zimbabwean policy makers should establish additional complementary policies which foster economic integration with anchor countries to reduce credit risk. On the other hand, dollarisation should be maintained since it resulted in economic stability and improved financial sector credibility. It is therefore still premature to de-dollarise the economy until a sufficient level of credibility is gained by the central bank.
\end{abstract}

Keywords: dollarisation; economic growth; economic integration; business cycles

\section{Introduction}

The Zimbabwean economy has been characterised by several monetary and fiscal challenges, hyperinflation, liquidity constraints, deindustrialisation and high interest rates (Mpofu 2015; Sikwila 2013). As a consequence, the monetary authorities introduced a multicurrency regime in an attempt to solve the aforementioned economic challenges (Reserve Bank of Zimbabwe (RBZ) 2016). The multicurrency regime included the use of a basket of currencies namely the United States dollar (USD), South African rand, Botswana pula, pound sterling, Euro, Australian dollar, Chinese yuan, Indian rupee and Japanese yen as legal currencies. However, the term 'dollarisation' became commonly used to refer to Zimbabwe's multicurrency regime for two reasons. Firstly, Havrylyshyn and Beddies (2003) defined dollarises as the use of any foreign currency for transactionary purposes, whilst Winkler et al. (2004) added that a nation will have to forego its central bank when it dollarises. Thus, by implication, the legalisation of any of the currencies in the basket becomes dollarisation by definition. Secondly, the term dollarisation became commonly used to refer to the multicurrency regime because more than $85 \%$ of the transactions were denominated in terms of USD. Thirdly, the budget for the Zimbabwean government was denominated in USD.

The two main aims of dollarizing were achieving monetary stability and restoring financial sector credibility which was lost due to hyperinflation. After officially dollarizing in 2009, the most immediate and noticeable effect of dollarisation was a drastic reduction in inflation to creeping levels. An economic rebound was felt between 2009 and 2012 before the economy started to subside again (African Development Bank (AfDB) 2014). Furthermore, most major macroeconomic indicators except for unemployment began to take a positive drift after dollarisation (Confederation of Zimbabwe 
Industries (CZI) 2014). The positive drift was, however, not sustained since it lasted only for three years, that is, until 2012. Thereafter, macroeconomic variables either stagnated or declined. Analysts have attributed the economic stagnation to dollarisation. Figure 1 below gives a picture of how the economy boomeranged in 2012 after dollarisation.

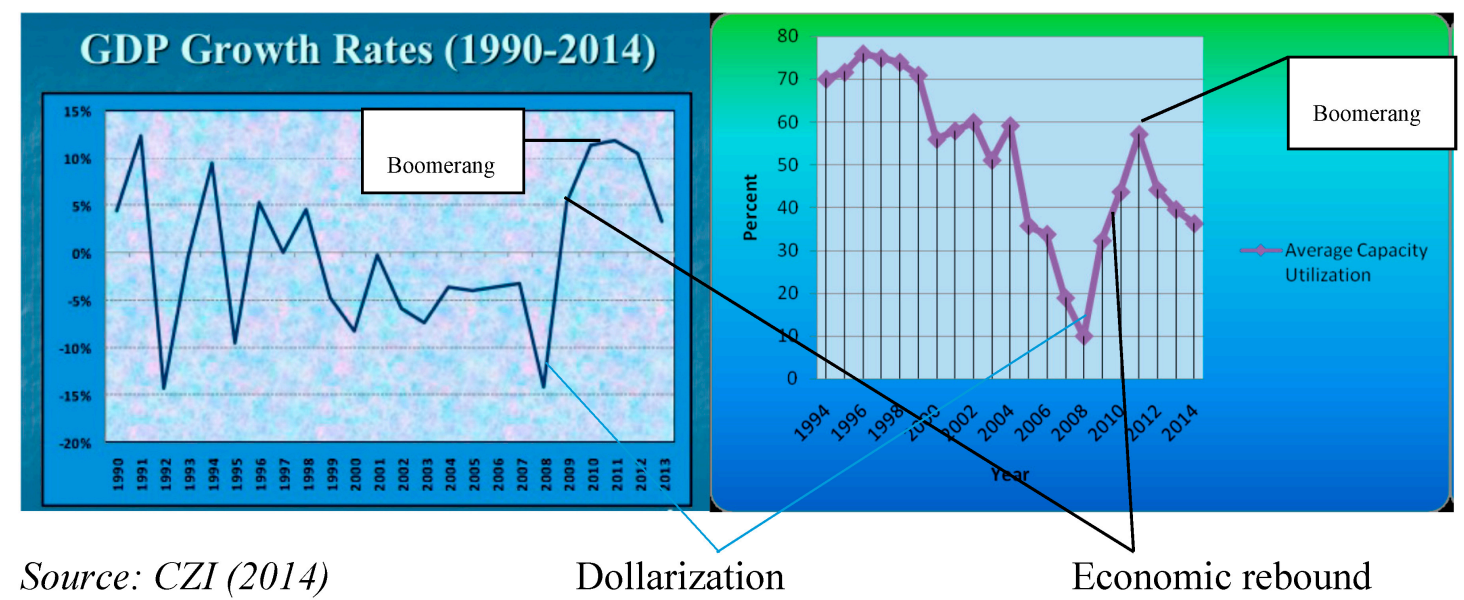

Figure 1. Trends in GDP Growth rates and Capacity utilisation.

Central to the problem is that as of 2019, the Zimbabwean economy has remained fragile and has been characterised by high inflation, high liquidity constraints, high interest rates, unsustainably high external liabilities, massive deindustrialisation and informalisation. Economic stagnation has largely been attributed to liquidity challenges as a result of dollarisation (Reserve Bank of Zimbabwe (RBZ) 2018). Thus, dollarisation brought with it its fair share of challenges. It deprived an economy of its monetary policy sovereignty, thereby, limiting the role of the central bank to merely regulation. The RBZ could no longer use its instruments of either money supply or interest rates to influence economic activities (Hanke and Alex 2009). Furthermore, a negative trade balance was stimulated because dollarisation meant that exports would be expensive whereas imports would be cheaper. This is supported by economic trade theory which states that exports become expensive reducing the competitiveness of a small economy (Krugman 1990). As a result, the economy experienced liquidity constraints that stifled the growth of the economy. The liquidity constraints emerged because, although the version of Zimbabwean dollarisation was official in the sense that was legalized by the Zimbabwean government, it was also considered by others as unofficial because there was no formal agreement between the RBZ and the Federal Reserve of the United States of America and other respective central banks so that they could provide some foreign currency as stimuli to the Zimbabwean economy. Thus, the majority of the USD and other foreign currencies were coming as scattered remittances, income from precious metals, tobacco and other exports. However, this was not sufficient to sustain the liquidity needs of the economy resulting in liquidity challenges.

The second research problem emanates from scant studies on dollarisation. Musoke (2017) acknowledges that that there are very few observed cases of dollarisation and history provides very little guidance on its consequences. Therefore, there is a research opportunity to examine dollarisation in the African context and also in the modern era. The paper seeks to answer the question of whether or not dollarisation affected economic growth in Zimbabwe. Related to this overarching objective is the complementary aim of establishing the extent to which interest rates have affected economic growth in Zimbabwe during the dollarisation era. In addition, the study also aims to establish what sort of effect trade openness had on economic growth in a dollarised Zimbabwe. Consequently, the following hypotheses were formulated: dollarisation positively impacted economic growth, interest rate negatively affects economic growth in Zimbabwe, and trade openness positively impacts the Zimbabwean economy. The analysis is restricted from the year 2000 when the economy began to experience significant macroeconomic challenges after moving out of the Commonwealth to the year 
2015 when the Zimbabwean central bank introduced bond notes, a fiduciary Zimbabwean currency whose issuance was claimed to be backed by Afrixembank (Reserve Bank of Zimbabwe (RBZ) 2016). The paper is organised as follows. Firstly, is the brief overview of the Zimbabwean economy, followed by a theoretical and empirical literature review. The paper then explains the methodology employed that will be followed by a regression analysis and policy recommendations.

\section{Overview of the Zimbabwean Economy (2000-2015)}

In retrospect, the Zimbabwean economy was characterized by hyperinflation for almost a decade (1998-2008). During this era, inflation figures rose from 48 percent in 1998 to 585.85 percent in 2005 and 66,212 percent in 2007 (Hanke and Alex 2009). The inflation rate reached its peak between August and November 2008 with approximate figures reaching around 79,600,000,000 percent annually and daily equivalent inflation approximately $98 \%$ (Hanke and Alex 2009). In addition, the economy showed a sliding trend in economic growth because of budget deficits, foreign currency shortages, and a decrease in commodity prices and drought (World Bank 2015). Thus, the Reserve bank decided to print more money (bearer's cheque) with the view of stimulating economic activity and decreasing the budget deficit (Reserve Bank of Zimbabwe (RBZ) 2018). This further fuelled the rate of growth of inflation and suppressed the exchange rate that led to the emergence of the black market.

In an attempt to mitigate hyperinflation (due to seignorage revenue to finance government recurring expenditures and quasi-fiscal programs, where this seignorage revenue was not backed by increases in productivity and production), the monetary authorities introduced multi-currency such as the rand and pula pegged against the US dollar (World Bank 2015). The introduction of multi-currencies stabilised the Zimbabwean economy for half a decade. However, this stability was for a short time as people started to intensify black market activities. The monetary authorities then decided to fix the exchange rate which in turn led to unstable and erratic exchange rate operations and many people had to resort to barter trade (Kanyenze et al. 2017). Economic stakeholders started substituting local currency with foreign currency in transactions to hedge themselves against hyperinflation. The continued crisis increased the use of foreign currency in the black market. Ever since the Reserve bank demonetarised in 2009, there has been no certified currency to date (Price WaterHouse Coopers (PWC) 2018). However, other challenges constraining the Zimbabwean economy include out-dated technologies, inconsistent economic policies, infrastructure deficits, operational bottlenecks, power shortages, lack of integrated financial and administrative systems and a volatile and fragile global financial atmosphere (African Development Bank (AfDB) 2014).

\section{Literature Review}

\subsection{Theoretical Literature Review}

Theoretical discussions on dollarisation can be viewed from the currency substitution theory, the bipolar view and Optimum Currency Area (OCA) view. Girton and Roper (1977) argued that currency substitution refers to the degree that currencies substitute in the portfolios of wealth holders. Currency in this context was referred to as money, as opposed to interest bearing assets that are considered in the capital accounts. Friedman (1953) and Johnson (1972) advocated against hard pegs such as dollarisation because currency substitution (or dollarisation) would incapacitate the domestic monetary policy as with the current experience of Zimbabwe where the central bank has limited or no influence over monetary instruments. However, proponents of currency substitution, who include Miles (1978) and McKinnon (1982), argued that economic agents who hold both domestic and foreign currencies and variations in interest rates or expected future exchange rates will make the domestic exchange rate unstable because economic agents will switch resources to maximize returns on their monetary holdings. The currency substitution theory is relevant in Zimbabwe because it explains the rationale behind economic agents' preferences to hold foreign currency in their portfolios during the crisis period between 2008 and the time the government dollarised in early 2009. Zimbabweans were 
holding both Zimbabwean dollars and foreign currency, especially USD, as a hedging mechanism from hyperinflation and asymmetric shocks.

The second theoretical argument is the bipolar view. This view attaches much weight on the benefits a country would gain by regaining monetary credibility. The bipolar view argues that dollarisation is a much faster and cheaper way of regaining credibility compared to more orthodox measures (Winkler et al. 2004). The credibility of the domestic monetary policy is considered the most significant factor in choosing a proper exchange rate regime. According to Summers (2001) and Calvo (2001), countries with a low degree of monetary policy credibility are severely limited in their capacity to use monetary policy to reduce output fluctuations and cannot act as an effective lender of last resort (LOLR). Consensus amongst many economists seemingly emerged that assuming open capital accounts, hard pegs are regarded as sustainable in most emerging markets (Frankel 1999; Fisher 2001). Hence, countries with open capital accounts or plans to liberalise capital flows should choose in favour of dollarisation. In line with the bipolar view, Zimbabwe gained monetary credibility because of dollarisation. This resulted in an increase in economic activity since investor confidence improved. When inflation decreased to less than $5 \%$ in 2009, the economy became more stable and planning became more possible thereby improving the credibility of the country. This credibility became compromised in 2016 when the RBZ issued 'bond notes' against the advice of almost all industry stakeholders.

Mundell's (1973) new view on OCA with international risk sharing explained how exchange rate uncertainty will interfere with the economy. The new view assumes that once a currency is well managed, larger currency areas will be preferred as opposed to smaller ones. In contrast to the old view, the new OCA theory argues that asymmetric shocks are not considered significant because of the existence of a common currency. This is because shocks are spread across the whole region and are dampened, whereas, in a flexible exchange rate regime, the cost will be concentrated on individual regions since devaluation will reduce its purchasing power. Therefore, according to the new OCA theory, the long run ineffectiveness of the monetary policy, low credibility and an ineffective exchange rate system are enough illnesses for an economy to dollarise. Winkler et al. (2004) supports this view by highlighting that the cost of losing monetary policy instruments becomes negligible in this view. Whereas the new OCA theory stresses the benefits of dollarisation on economic stability, the old view highlights the integration prerequisites of dollarisation.

In summary, stability and integration are the two main issues that can be derived from the theoretical literature. On one hand, dollarisation is seen from a stability point of view as a tool to eliminate the credibility problem and therefore enhancing macroeconomic and financial stability which in turn create the necessary environment for growth. The bipolar view and the new OCA theory are in favour of the stability argument. Therefore, using these views, we expect dollarisation to have a positive effect on economic growth. On the other hand, dollarisation is viewed from an integration perspective where it is linked to the degree of economic and financial integration with the anchor country. On the integration angle, some advocate for an ex ante integration to warrant sustainability while others argue for an ex post integration depending on endogenous tendencies related to the adoption of the foreign currency (Winkler et al. 2004). The Zimbabwean economy is not integrated with anchor countries like USA, South Africa, India and Europe, making dollarisation less effective to some extent. In conclusion, stability and credibility remain key points attached to dollarisation and economic growth.

\subsection{Empirical Literature}

There are very few recent observed cases of dollarisation in the empirical literature Musoke (2017), Lakić et al. (2016), Anderson (2016) and Naceur et al. (2015). Anderson (2016) and Mpofu (2015) support the idea that dollarisation might lead to shocks becoming more synchronized which leads to real convergence in terms of Gross Domestic Product (GDP) levels. Contrary to this view, Goldfajn and Olivares (2000) argued that dollarisation could increase a country's default risk, thus contributing to a higher risk premia if the loss of the exchange rate instrument reduces a country's 
adjustment capacity to asymmetric shocks. Higher default risk is reflected by high lending rates to investors. In this view, bankers in Zimbabwe have cited high credit risk as a justification for high interest rates in the dollarised era. In addition, Goldfajn and Olivares (2000) purport that dollarisation does not preclude the sovereign defaults of an economy emanating from an unsustainable fiscal position, unsound financial systems or political turmoil which will further lead to divergence from those of the anchor country. Therefore, according to this argument, interest rates will remain significantly high and will deter growth in Zimbabwe until financial and political systems have been restructured to complement a dollarised regime. Using the dynamic panel data model to investigate how to de-dollarise financial systems in Central Asia, Naceur et al. (2015) found that dollarisation is driven by inflation and weak exchange policies. The same results were obtained by Edwards and Magendzo (2001) who concur that dollarisation leads to price stability. Using a matching estimator technique, Musoke (2017) investigated whether dollarisation is associated with lower inflation and faster economic growth. The results suggested that inflation has been significantly lower in dollarised economies compared to non-dollarised ones. However, results showed that dollarised nations had lower economic growth than non-dollarised ones and that macroeconomic volatility is not significantly different across countries. The authors conjecture that lower economic growth in dollarised countries is partly because of difficulties in accommodating external shocks is explained by the OCA theory, for instance, difficulties in accommodating shocks in major terms of trade and capital flows.

Lakić et al. (2016) argued that dollarisation supports the development of a country's financial sector and that a stable currency is a precondition for financial development. The authors further argued that dollarised economies enjoy higher levels of confidence among investors and a lower interest rate spreads on their international borrowing. This fosters international trade, reduces fiscal costs and boosts investment growth. In the same vein, dollarisation leads to lack of independence by monetary authorities in Montenegro. Reflecting on Argentina's currency boards and the choice of whether to dollarise or not, Aschinger (2004) empirical results showed that even with a currency board, it is difficult to restore stakeholder's confidence or monetary credibility considering a crisis has been developing for years. This crisis could be characterized by economic disparities such as high unemployment, buoyant inflation or staggering economic growth. Understanding of the hysteresis effect will help policy makers grasp the reality that de-dollarisation is not easily acceptable even after economic stability and monetary credibility has been regained.

In the study of Peru, Moron and Castro (2003) used a portfolio approach on 14 Latin American countries to explore de-dollarizing the economy and the study highlighted that financial dollarisation creates design problems for economic policy since it increases the level of financial vulnerability. They proposed two policies, increasing the risk of dollar deposits and increasing the relative volatility of inflation via real depreciation. The results suggest that the former has the potential risk of lowering the level of financial intermediation whilst the latter is more effective to de-dollarise the economy. The portfolio approach could provide some useful tools in the event that Zimbabwean policy makers are seriously considering to de-dollarise. Furthermore, Ize and Parratoi's (2005) study explored the dynamic interaction between real dollarisation (dollar indexing of wages), financial dollarisation and monetary policy. The authors used a general equilibrium model with real shocks. They found that local welfare is maximized if real dollarisation is avoided as long as the domestic monetary authorities perform optimally. Their findings are a fusion of the bipolar view and the old OCA theory. They highlighted that dollarisation occurs when the central bank performs poorly and is accelerated when the correlation between domestic and external shocks is high.

Eichengreen (2000), Molano (2000) and Edwards and Magendzo (2001) all asserted that there is no sufficient evidence that countries that dollarised are more fiscally prudent and the behaviour of current account imbalances is no different. Eichengreen (2000) used dynamic panel data analysis, Molano (2000) both employed Auto Regressive Distributive Lag (ARDL) whilst Edwards and Magendzo (2001) used the matching estimator technique. Their findings are relevant for Zimbabwe because the nation is experiencing consistent budget deficits and current account imbalances even after dollarisation. The 
researchers conjecture that current account imbalances are a result of difficulties in accommodating external shocks, an argument raised in the 'old' OCA theory. However, studies in Chile by Edwards and Magendzo (2001) acknowledged that dollarised economies had lower inflation and experienced faster growth. Zimbabwe has also experienced lower inflation since dollarisation but it is not yet clear whether dollarisation increased growth in Zimbabwe, hence, this study intends to fill in the literature gap by investigating if dollarisation had a positive effect on economic growth in Zimbabwe.

In the same period Grandes (2001) explored external solvency, dollarisation and investment in Argentina. Their study used a Vector autoregression (VAR) analysis and showed that a significant endogenous relationship between GDP growth, fiscal debt and country risk holds. Results exhibited that reducing interest rates on foreign currency was less significant than reducing interest rates on peso $^{1}$ due to varying interest rate spreads. The study shows the significance of interest rate spreads in a dollarised Argentina. Whilst theoretical and empirical literature suggests that dollarisation lead to lower interest rate spreads, Zimbabwe is still faced by high interest rates spreads which are as high as $17 \%$ which have limited the level of investment. High interest rate spreads in Zimbabwe have been attributed to liquidity constraints and high credit risk. Secondly, Argentine external and fiscal vulnerability sharply worsened between 1994 and 1999. The third result was that dollarisation is not the best policy to improve fiscal discipline and make structural reforms a success. The same evidence is held by Edwards and Magendzo (2001), and Goldfajn and Olivares (2000) who support that a full dollarisation regime did not generate fiscal discipline for Panama. Therefore, dollarisation in Zimbabwe needs other complementary policies that promote fiscal discipline, for instance, focusing on capital expenditure as opposed to recurrent expenditures such as salaries and wages. At present, there are no significant institutional reforms in Zimbabwe to support a dollarisation policy.

Using a model applied by Tanzi (1983) and adjusting minor changes to the specification of the demand for currency model to incorporate the effects of dollarisation of the economy of Pakistan, Aslam (1998) studied the underground economy and tax evasion in Pakistan and considered the impact of dollarisation in the economy for the period 1960-1998. The Tanzi model was developed by Tanzi in 1983 to investigate the nature and size of non-measured economy. ${ }^{2}$ The original model lacked a base year and Aslam (1998) adjusted it by including more relevant variables such as tax evasion, demand for foreign currency, and interest on time deposits and also measured the underground economy for the period concerned in order to increase the accuracy of the estimates. To incorporate dollarisation of the economy, the author included a new variable which consists of resident foreign currency accounts along with foreign currency in circulation (CFCA). Demand for foreign currency is measured by the CFCA to money supply (M2). The results showed among other factors, that structural reforms and introduction of foreign currency accounts increased the degree of dollarisation in Pakistan.

The findings of Aslam (1998) are significant to the Zimbabwean context because they relate to how the dollarisation process took place in Zimbabwe. Foreign currency found its way into the Zimbabwean economy through the use of foreign currency accounts during the hyperinflation era. Stakeholders would then leak the foreign currency into the informal and illegal markets to evade taxes when transacting. The study by Aslam (1998), which used the Tanzi method, is significant because it highlights the significance of the need to measure and approximate the amount of foreign currency in the informal and illegal economy. The inclusion of foreign currency deposits plus the currency in circulation in the formal, informal and illegal market will assist policy makers in Zimbabwe to come up with more accurate estimates of the degree and extent of dollarisation both in the formal and underground economy. This will assist in mapping correct strategies in structural reforms to synchronise the formal and underground economy. Similar to the case of Pakistan, there is need to pay attention and consider the dynamics of the underground economy in Zimbabwe because approximately

Argentine currency.

Both informal and illegal economy. 
$70 \%$ of the labour force are employed informally implying a significant proportion of foreign currency is circulating in the underground economy in Zimbabwe and there is a high incidence of tax evasion in Zimbabwe (Zimbabwe Revenue Authority (ZIMRA) 2019).

The significance of underground economies with regards to dollarisation was also confirmed by Sosic and Faulend (2002) for Croatia. The paper used ARDL approach and used remittances and foreign currency deposits as a proxy for dollarisation. The study also employed the adjusted Tanzi method to approximate the size of the underground economy for Croatia. They brought supporting evidence that foreign currency is linked with underground economies in countries where the phenomenon of dollarisation is widespread. They then suggested that there should be more understanding on the extent and dynamics of dollarisation as this will provide important information about the dynamics of underground economies. In other words, understanding dollarisation dynamics is a more efficient and effective way of understanding underground economies. The authors, however, noted that their estimates are of an indicative nature only and maybe be subject to criticism. Thus, their objective was to draw more consideration to the importance of dollarisation for underground economies exploration than to provide final estimates.

Further research was later done by Winkler et al. (2004) who investigated the motives, features and policy implications of dollarisation for several countries across the globe. The authors used a qualitative analysis in their study. They recommended that policies should foster integration with the anchor country particularly in fiscal transfers, tourism and offshore finance which are critical in supporting the exchange rate regime of dollarisation. In other words, their findings support the 'old' OCA theory. Zimbabwe is currently not highly integrated with its anchor countries thus placing a limit on the benefits of dollarisation. Integration can be improved by lessening visa requirements thus promoting free labour movement, reducing language and cultural barriers, removing economic sanctions and engaging in trade agreements. In 2006, Cohen analysed United States policy on dollarisation and focused on the potential costs and benefits of dollarisation. The pros and cons are both economic and political. Cohen suggested that there exists no clear presumption regarding U.S interest leaving wide latitude for policy direction and he expects continued passive neutrality from the Federal Reserve with only the possibility of the Euro posing a serious contest to the dollar's global supremacy and this might stimulate a competitive response from Washington. Despite highlighting several pros and cons of dollarisation of which most of them exists in other literature ${ }^{3}$, the paper will not contribute much to our investigation because it placed its attention on the American economy and the European area. Its analysis was mainly focused on the potential threat to the USD that could be brought by the Euro since the Euro was now replacing the USD in Europe, which is a new 'currency area'. The other weakness of the paper is that Cohen (2002) used a qualitative analysis in his paper thereby making his arguments subjective.

Reflecting on Argentina's currency boards and the choice of whether to dollarise or not, Aschinger's (2004) empirical results showed that even with a currency board, it is difficult to restore stakeholders' confidence or monetary credibility considering a crisis has been developing for years. This crisis could be characterised by economic disparities such as high unemployment, buoyant inflation or staggering economic growth. These findings are also significant because they explain why Zimbabwean policy makers are still battling to restore stakeholders' confidence in the financial sector several years after the 2008 crisis. This has resulted in several challenges such as reduced bank deposits and low investment levels even years after the economy has stabilised since both depositors and investors are still sceptical about future policies in Zimbabwe. For instance, even though the majority of economic stakeholders were aware that the central bank was trying to address the current liquidity crisis, the recent introduction of the 'bond coins' by the central bank was not initially well accepted by economic stakeholders although the bond coins were pegged at an exchange rate of 1:1 with the USD. Aschinger

3 For a summary of arguments for and against dollarization, see Table 1 below. 
(2004) further asserted that after economic stabilisation in Argentina, statistical analysis showed that overheating effects showed up in several countries which would manifest in difficulties in the banking or real estate sector. The study concludes by reflecting that it is generally difficult to judge future implications of policy measures such as currency boards given the chaotic situation of the country. The crisis can only be subjugated by changing internal structures, improving institutions and reducing corruption coupled with international assistance.

In the study of Peru, Moron and Castro (2003) used a portfolio approach to explore de-dollarizing the economy. Upon indicating that countries with high dollarisation have not done anything to reduce it, the study highlighted that financial dollarisation creates design problems for economic policy since it increases the level of financial vulnerability. The study performed cointegration analysis and panel estimation of 14 Latin American countries. A Vector Error Correction Model (VECM) was also specified and econometric tests were performed. Two policy alternatives which emphasize on the portfolio approach were proposed, that is, increasing the risk of dollar deposits and increasing the relative volatility of inflation via real depreciation. The results suggested that the former has the potential risk of lowering the level of financial intermediation whilst the latter is more effective to de-dollarise the economy. The portfolio approach could be taken into account in the event that Zimbabwean policy makers are seriously considering de-dollarising but currently there are no serious signals of de-dollarising in Zimbabwe.

However, a study was conducted by Makoto (2012) with regards to de-dollarising in Zimbabwe. In his exploration on the macroeconomic effects of full dollarisation and the viability of dedollarisation in Zimbabwe, Makoto (2012) concluded that the economy stabilised as a result of full dollarisation. He, however, reiterated that stability came at the expense of the loss of economic policy independence. He further highlights that the Zimbabwean economy does not currently possess conditions of successful de-dollarisation, namely, a sustainable current account balance, improved capacity utilisation and central bank reform. They recommended that Zimbabwe can adopt market driven de-dollarisation by first introducing coins less than $\$ 1$ backed by gold and diamonds with a one-to-one exchange rate. This will facilitate smaller transactions in the economy making them acceptable to the general public. Makoto's (2012) recommendation has since been adopted by the central bank in 2015 with the introduction of 'bond coins' which are backed by the AfDB. The author further highlighted that following the consolidation of gains in economic performance, authorities can broaden the use of Zimbabwean dollars (ZW\$) together with the USD. Makoto (2012) preferred gradual de-dollarisation to randisation (adoption of rand) as this will lead to persistent loss of policy independence.

Quispe Misaico (2000) researched transmission mechanisms of monetary policy in the partially dollarised Peruvian economy. Dollarisation in Peru was mainly as a result of asset substitution since domestic currency is mostly used for transactionary purposes. The author used a model based on Quispe (2000) and Bernanke and Mihov (1998) and applied a VAR analysis where the independent variables were monetary policy variables and dependent variables were non-policy macroeconomic variables. One represented policy maker's reaction functions and the other represented structural relationships that describe the transmission mechanism. Results indicated that inflation in Peru is driven by demand shocks and monetary shocks are significant and account for 30\% to $40 \%$ of the variance in inflation rate. Zimbabwe is also a small economy and the results of Peru signalled the need to monitor demand and monetary shocks. These asymmetric shocks were considered significant by the 'old' view of the OCA theory.

Ize and Parratoi's (2005) study explored the dynamic interaction between real dollarisation (dollar indexing of wages), financial dollarisation (dollar denomination of financial contracts) and monetary policy. The authors used a general equilibrium model with real shocks. They found that local welfare is maximised if real dollarisation is avoided as long as the domestic monetary authorities perform optimally. Their findings are a fusion of the bipolar view and the 'old' OCA theory. They 
highlighted that dollarisation occurs when the central bank performs poorly ${ }^{4}$ and is accelerated when the correlation between domestic and external shocks is high. ${ }^{5}$ They further highlighted that although real dollarisation significantly contributes to financial dollarisation, significant asymmetries between the two exist. They used a model similar to the ones developed by Corsetti and Pesenti (2001, 2005), Devereux and Engel (2002, 2003) and Chang and Velasco (2002) where the money demand equation is a function of the inverse of gross national interest rate and the model was blended in a new-Keynesian fashion

In his study on the implications of dollarisation for Belize, Ford (2001) highlighted two clear immediate benefits of dollarisation namely the elimination of currency risk and lower transaction costs. The elimination of currency risk was the major benefit for Zimbabwe when it dollarised since inflation sharply declined in February 2009. The need to hedge against hyperinflation was immediately eliminated. In addition, transaction costs were also minimised in Zimbabwe as asserted by Cohen (2002), Makochekanwa (2009) and Sikwila (2013). Transaction costs are in the form of currency conversion and hedging. Ford (2001) further highlighted that operations in the parallel market do not cease as in the case of Liberia because of inadequate US dollars, solvency challenges and civil unrest. The findings partially explain why a parallel market still exists in Zimbabwe even after official dollarisation. The continued existence of a parallel market could be fuelled by liquidity shortages that currently exist as a result of dollarisation. However, the paper by Ford (2001) found it difficult to statistically ascertain the dollarisation benefits and domestic and international business rates differentials. This is because, where interest rates are concerned, dollarisation was accompanied by additional legislative measures to ensure that any cost savings derived from lower reserve requirements are passed through to the general public. For instance, Ecuador and El Salvador passed legislature to enforce banks to lower lending rates as part of their dollarisation program. In other words, interest rates were not left to the invisible hand of market forces and as such we cannot conclusively say dollarisation lowers interest rate differentials. Their observation possibly explains why interest rate differentials have not reduced in Zimbabwe since 2009 because there has not been any legislative intervention to force interest rates down as with the case of Ecuador and El Salvador.

Bahmani-Oskooee and Domaç (2003) investigated the role of dollarisation in the dynamics of inflation in Turkey. Descriptive analysis suggests that despite high inflation and economic instability, institutional factors played a significant role in the evolution of dollarisation in Turkey. Results indicated that shocks to dollarisation led to a decrease in the monetary base since the public switched from domestic to foreign money balances. The findings complement the 'old' OCA theory which asserts that a dollarised economy loses adjustment mechanisms in the event of external shocks and the monetary base of Zimbabwe will be heavily affected by such asymmetric shocks. Institutions have also played a significant role in influencing the evolution of dollarisation and economic growth in Zimbabwe. The dollarisation process started in the informal and illegal market until it came to a point where the Government had no option but to dollarise, thus, institutions were very significant in the evolution process of dollarisation. After official dollarisation, institutions have dampened rather than amplified economic growth in Zimbabwe. For instance, approximately 60\% of Zimbabwe's government revenue is channelled towards recurrent expenditures salaries (Government Budget 2014) leaving only a small proportion for gross domestic investment.

Berg and Borensztein (2000) and Calvo (2000) argued that dollarisation supports development of a country's financial sector and that a stable currency is a precondition for financial development. ${ }^{6}$ They further argued that dollarised economies enjoy higher level of confidence among investors and lower interest rate spreads on their international borrowing. This fosters international trade, reduces

\footnotetext{
The bipolar view stresses poor performance of the central bank and the need to restore credibility by dollarizing. The 'old' OCA theory places weight on asymmetric shocks and the need for adjustment mechanisms.

This is a well known stylised fact.
} 
fiscal costs and boosts investment growth. However, Makochekanwa (2009), Chigome (2011), Sikwila (2013) and Nkomazana and Niyimbanira (2014) are of the view that the RBZ can no longer gain from seignorage revenue. This includes both once-off 'stock' arising from replacing the national currency in circulation with foreign bank notes and the 'flow' costs arising from loss of future earnings curtailing from the flow of new currency printed each year. The loss in seignorage revenue results in lack of the financial stimulus needed to boost economic activity. The inability of the central bank to print money explains the current liquidity constraint in Zimbabwe.

Frankel and Rose (2002), Rose and Engel (2000) and Dallas and Tavlas (2001) support the idea that dollarisation might lead to real convergence, in terms of GDP levels, and convergence of business cycles with the issuing country. They further support that shocks also become more synchronised thereby further promoting integration. This is in support of the OCA theory. Contrary to this view Goldfajn and Olivares (2000) argued that dollarisation could increase a country's default risk thus contributing to higher risk premia if the loss of exchange rate instrument reduces a country's adjustment capacity to asymmetric shocks. Higher default risk is reflected by high lending rates to investors. Bankers in Zimbabwe have cited high credit risk as a justification for high interest rates in the dollarised era. In addition, Goldfajn and Olivares (2000) purports that dollarisation does not preclude the sovereign defaults of an economy emanating from an unsustainable fiscal position, unsound financial systems or political turmoil which will further lead to divergence rather than convergence as earlier argued. Zimbabwe did not restructure its financial and political systems even after dollarisation and this could explain why interest rates have been diverging from those of the anchor country. Therefore, according to this argument interest rates will remain significantly high and deterring growth in Zimbabwe until financial and political systems have been restructured to complement a dollarised regime.

In Africa, a study was conducted in 2011 by Panteleo (2011) who researched dollarisation in Tanzania using empirical evidence and cross-country experience. The study investigated the stylised facts of dollarisation in Tanzania and the East African Countries (EAC) region since the use of the USD as a unit of account, store of value and medium of exchange was raising concerns amongst economic policy makers. The study showed that financial dollarisation is very high in Tanzania compared to other EAC countries. The study used primary data gathered using questionnaires which included 20 firms located in Dar es Salaam to determine the extent and driving force behind the use of USD as a unit of account for prices, salaries and financial reporting. Although their methodology was sound in the sense of obtaining primary data, their coverage was very limited and the region may not be representative enough for the whole country. This study is going to use secondary data because it is more relevant and effective to our analysis and will consider time series data rather cross sectional data. Time series data has the advantage of time heterogeneity whilst cross sectional data has the advantage of individual heterogeneity. Moreover, there will be national coverage in the statistics which will give us a much better representation.

Edwards and Magendzo (2001) investigated whether dollarisation is associated with lower inflation and faster economic growth. The analysis was done using a matching estimator technique which was developed in the training evaluation literature. The results suggested that inflation has been significantly lower in dollarised economies compared to non-dollarised ones. In addition, the results also indicated that dollarised nations had lower economic growth than non-dollarised ones and that macroeconomic volatility is not significantly different across countries. The authors conjecture that lower economic growth in dollarised countries is partly because of the difficulties in accommodating external shocks as explained by the OCA theory, for instance, major terms of trade and capital flows shocks. In their coverage, they did not include Zimbabwe and this study intends to investigate also on the relationship between dollarisation and economic growth in Zimbabwe, that is, whether the results for Zimbabwe will still be consistent with the findings of Edwards and Magendzo (2001).

Nkomazana and Niyimbanira (2014) investigated the overview of the economic causes and effects of dollarisation in Zimbabwe. They examined the failure of the banking system in providing currency to economic stakeholders, that is, firms and individuals. The paper concluded that dollarisation 
eliminated inflation instantly and reduced capital flight. Although the paper considered not only the causes but also the effects of dollarisation in Zimbabwe, the authors did not use econometric techniques in their analysis which leaves some gaps in the study since the conclusions are based on subjective rather than objective arguments. In this study, we are going to apply econometric methods to come up with more robust conclusions for our policy makers and other economic agents. In addition to the above literature, Table 1 below shows a summary of the studies which advocated for and against dollarisation.

Table 1. Arguments for and against dollarisation.

\begin{tabular}{ll}
\hline \multicolumn{1}{c}{ Author and Year } & \multicolumn{1}{c}{ Argument(s) for Dollarisation } \\
\hline Cohen (2002) & $\begin{array}{l}\text { Reduces transaction costs by eliminating expenses in currency conversion or } \\
\text { transactions in hedging. } \\
\text { Brings greater stability to economies which create a conducive environment for } \\
\text { trade and investment. }\end{array}$ \\
\hline $\begin{array}{l}\text { Fisher (2001); Barro and } \\
\text { Gordon (1983); Goldfajn and } \\
\text { Olivares (2000) }\end{array}$ & $\begin{array}{l}\text { Fosters macroeconomic stability since it solves the credibility issue that arise } \\
\text { when central bank is unable to pre-commit itself to a low rate of inflation. } \\
\text { Interest rates are assumed to converge towards the level of the anchor country. }\end{array}$ \\
\hline Eichengreen (2000) & $\begin{array}{l}\text { Promote fiscal discipline by eliminating the possibility of printing money to } \\
\text { finance debts. }\end{array}$ \\
\hline Goldfajn and Olivares (2000) & $\begin{array}{l}\text { Leads to lower risk premium because a sharp and sudden devaluation is ruled } \\
\text { out by definition. }\end{array}$ \\
\hline $\begin{array}{l}\text { Berg and Borensztein (2000); } \\
\text { Calvo (1999) }\end{array}$ & $\begin{array}{l}\text { Improves a country's access to international capital markets as a result of lower } \\
\text { currency risk, higher financial sector stability, lower risk of sudden introduction } \\
\text { of capital controls and lower information costs }\end{array}$ \\
\hline
\end{tabular}

Support development of country's financial sector. It is a well-known stylised fact

Hausmann et al. (2006); Berg and Borensztein (2000) that a stable currency is a precondition for financial development. Dollarised economies enjoy higher levels of investor confidence, lower interest rate spreads on their international borrowing, reduced financial costs and more investment growth

Frankel and Rose (2002); Rose and Engel (2000); Dallas and Tavlas (2001) Fosters a country's economic integration with the economy of the issuing country. Dollarisation might lead to real convergence in terms of GDP levels and convergence of business cycles with the issuing country. Shocks might become more synchronised further fostering integration.

Winkler et al. (2004) Dollarisation is seen as one way of accepting the impossible trinity.

\begin{tabular}{cl}
\hline Author and Year & \multicolumn{1}{c}{ Argument(s) against Dollarisation } \\
\hline Cohen (2002) & $\begin{array}{l}\text { Dollarisation has no direct impact on other critical deficiencies such as fiscal } \\
\text { indiscipline, poor banking supervision and labour market rigidities. }\end{array}$
\end{tabular}
indiscipline, poor banking supervision and labour market rigidities.

Dollarisation could increase a country's default risk thus contributing to higher

Goldfajn and Olivares (2000) risk premia if the loss of exchange rate instrument reduces a country's adjustment capacity to asymmetric shocks.

Dollarisation does not preclude sovereign defaults resulting in unsound financial systems or political turmoil.

Countries lose use of monetary policy instruments as an adjustment mechanism

Winkler et al. (2004) in the wake of asymmetric shocks. Central banks can no longer react to fluctuations in the business cycle that are not related the anchor country, for example, sudden bank runs.

Berg and Borensztein (2000); No lender of last resort (LOLR).

Makoto (2012) Loss of policy independence.

Sikwila (2013); Chigome (2011);

Makochekanwa (2009);

Nkomazana and Niyimbanira (2014)

Central banks cannot gain from seignorage revenues. This includes 'once-off' stock arising from replacing the national currency in circulation with foreign bank notes and the 'flow' costs arising from loss of new currency printed each year. 


\section{Economic Framework}

\subsection{Data and Model Specification}

In assessing the effects of dollarisation on economic growth in Zimbabwe, this study employed a quantitative approach assessing the period of 2000-2015. The sample size is restricted to the year 2000 because this is when the economy began to experience momentous challenges. To analyse these challenges, this study used quarterly data from 2000: Q1 to 2014: Q4. Data was obtained from the World Bank (2015) database with complementary data obtained from local sources. However, World Bank (2015) data was annual and was converted to quarterly data using the Linsman and Sandee (1964) technique. The data used includes the domestic interest rate, economic growth, dollarisation, gross domestic investment and trade openness. In analyzing the relationship between dollarisation and economic growth, the study follows the one country, two currency and economic growth model. The model specification follows the generic Equation (1) in log form:

$$
\ln \mathrm{GDP}_{t}=\beta_{0}+\ln \mathrm{GDPP} \_1+\lambda \ln \mathrm{I}_{t}+\gamma \ln \text { Trad }+\theta \text { Doll }+\omega \mathrm{GDI}+\varepsilon_{t}
$$

where $\ln G D P$ is economic growth, lnGDP_1 is lagged economic growth, lnI represent domestic interest rates, lnTrad is Trade Openness, Doll is a dummy variable measuring dollarisation, GDI is the Gross Domestic Investment and $\varepsilon$ is the white noise disturbance term assumed to be normally distributed with mean zero and constant variance. Further, $\beta$ is the constant and $\lambda, \gamma$ and $\omega$ are coefficients of the respective variables. Additionally, $\lambda$ was expected to have a negative sign and a positive sign for $\gamma$ and $\omega$ based on the view that trade openness and gross domestic investment should contribute appositive net financial inflow. Table 2 shows the variables, source, description and the expectation of the variables used in this study.

Table 2. Data description.

\begin{tabular}{|c|c|c|c|c|}
\hline Variable & Identifier & Source & Description & Expectation \\
\hline $\begin{array}{l}\text { Economic } \\
\text { growth }\end{array}$ & GDP & World Bank & $\begin{array}{l}\text { The ability of an economy to } \\
\text { produce more in terms of goods and } \\
\text { services over a given period of time } \\
\text { and it is usually a rate of change or } \\
\text { growth rate. }\end{array}$ & \\
\hline $\begin{array}{l}\text { Lagged income } \\
\text { per capita }\end{array}$ & GDP_1 & World Bank & $\begin{array}{l}\text { The income per capita of a } \\
\text { previous year. }\end{array}$ & $(-)$ \\
\hline Interest rate & I & World Bank & $\begin{array}{l}\text { The cost of borrowing since we are } \\
\text { using lending rates as our proxy. }\end{array}$ & $(-)$ \\
\hline Dollarisation & Doll & World Bank & $\begin{array}{l}\text { Dollarisation was measured by the } \\
\text { foreign currency deposits to the } \\
\text { (M2) broad money. This variable is } \\
\text { considered a dummy variable of } 0 \\
\text { from the 2000: Q1 and zero } \\
\text { otherwise. }\end{array}$ & $(+)$ \\
\hline $\begin{array}{c}\text { Trade } \\
\text { Openness }\end{array}$ & Trad & World Bank & $\begin{array}{l}\text { the sum of exports and imports } \\
\text { expressed as a share of gross } \\
\text { domestic product. }\end{array}$ & $(+)$ \\
\hline $\begin{array}{l}\text { Gross Domestic } \\
\text { Investment }\end{array}$ & GDI & World Bank & $\begin{array}{l}\text { GDI captures government and } \\
\text { domestic investment behaviour } \\
\text { implying it is a purely } \\
\text { exogenous variable. }\end{array}$ & $(+)$ \\
\hline
\end{tabular}




\subsection{Pre-Estimation Tests}

Pre-estimation tests were conducted to ensure that the model is free from spurious regressions. Firstly, the unit root test were conducted using the Augmented Dickey Fuller (ADF) test because it automatically solves the problem of serial correlation inherent in the error term (Asteriou and Hall 2007). Unit root tests also indicate if variables are integrated at $\mathrm{I}(0)$ and $\mathrm{I}(1)$, which are necessary conditions for the ARDL model.

Secondly, cointegration tests were conducted using the ARDL bound test (F-test). Cointegration tests are used to establish the presence of a long run relationship between variables (Mohapatra et al. 2016). If the calculated F-statistic is greater than the upper critical value, then the null hypothesis of no cointegration can be rejected. An F-value that lies within the region implies that the results are indeterminate while an F-value that is lower than the critical value implies cointegration (Pesaran and Shin 1999). If there is evidence of a long run relationship between dependent and independent variables, then ARDL is used to determine both the short-run and long-run.

\subsection{The Autoregressive Distributive Lag Model}

The ARDL models are regressions that have lags in both the independent and dependent variables (Ncanywa and Mabusela 2018). The advantage of this method is that it allows the variables that are integrated at zero and one to be analysed (Pesaran and Shin 1999). The test is considered to be more efficient in small data samples, which are characteristic of developing countries. The ARDL model is shown in Equation (2).

$$
\begin{aligned}
\Delta \ln Y=\varnothing_{0} X_{t}+ & \sum_{i=1}^{n} f_{i x} \Delta \ln Y_{t-i}+\sum_{i=1}^{n} g_{i x} \Delta \operatorname{Doll}_{t-i}+\sum_{i=1}^{n} h_{i x} \Delta \ln i_{t-i} \\
& +\sum_{i=1}^{n} k_{i x} \Delta \operatorname{trad}_{t-i}+\sum_{i=1}^{n} k_{i x} \Delta \operatorname{lnGDI} t-i \\
& +\Psi_{1 x} \ln Y_{t-1} \\
& +\Psi_{5 x} \ln \operatorname{Doll}_{t-1}+\Psi_{3 x} \ln i_{t-1}+\Psi_{4 x} \ln \operatorname{trad}_{t-1} \gamma_{i t}
\end{aligned}
$$

After analysing both the short-run and long-run results, post-estimation tests were conducted to ensure the reliability of results. Firstly, serial correlation and heteroscedasticity were conducted using the Breusch-Godfrey Serial Correlation Lagrange Multiplier (LM) test, Breusch-Pagan-Godfrey heteroscedasticity Test and the Jarque-Bera normality test. If the probability values of all these tests are above a 10 percent level of significance, then the null hypothesis cannot be rejected. This would imply that the study is free from heteroscedasticity and serial correlation.

\section{Estimation, Presentation and Interpretation of Results}

\subsection{Descriptive Statistics}

Table 3 indicates that the standard deviations are relatively small for all other variables except for Gross Domestic Product per capita-(GDPP) and interest rate-(I). This means that all the variables have small deviations from the mean as compared to GDP and I. All the variables have positive coefficients of skewness indicating that all are positively skewed. The next step is to analyse the correlation results.

\subsection{Correlation Analysis}

The correlation measured the association of the variables under the study and the results are illustrated in Table 4. The results indicate that all the absolute partial correlation coefficients are less than 0.8 and this implies that there is no multicollinearity among variables. The highest pairwise coefficient is that between Gross Domestic Investment (GDI) and Interest rate (I) which is 0.688 and it is acceptable. This means that exogenous variables in the model do not move together in systematic 
ways. In addition, although not shown in the tables below, the variance inflation factor (VIF) tests did not shown any significant changes from the conclusions drawn from the discussion above.

Table 3. Descriptive Statistics.

\begin{tabular}{ccccccc}
\hline & GDI & DOLL & GDP_1 & InI & lntrad & GDP \\
\hline Mean & 2.4989 & 0.4333 & 119.0281 & 51.9553 & 20.8754 & 119.028 \\
Median & 2.7721 & 0.0000 & 110.8455 & 16.4058 & 20.0051 & 110.845 \\
Maximum & 5.8116 & 1.0000 & 172.8769 & 252.0161 & 31.4914 & 172.876 \\
Minimum & -0.1741 & 0.0000 & 78.6815 & -32.2587 & 14.2197 & 78.6815 \\
Std.Dev & 1.5154 & 0.4997 & 25.5885 & 65.8231 & 4.0825 & 25.5885 \\
Skewness & 0.2202 & 0.2690 & 0.8446 & 1.3178 & 0.8864 & 0.8445 \\
Kurtois & 2.2114 & 1.0723 & 2.7649 & 3.8579 & 3.0442 & 2.7649 \\
Jarque-Bera & 2.0395 & 10.0131 & 7.2714 & 19.2067 & 7.8617 & 7.2714 \\
Probability & 0.3607 & 0.0067 & 0.0264 & 0.0001 & 0.0196 & 0.0264 \\
Observations & 60 & 60 & 60 & 60 & 60 & 60 \\
\hline
\end{tabular}

Source: Own Compilation.

Table 4. Correlation matrix.

\begin{tabular}{ccccccc}
\hline & GDI & GDP & lnI & lntrade & Doll & GDP_1 \\
\hline GDI & 1 & & & & & \\
\hline GDPP & 0.0516 & 1 & & & & \\
\hline $\ln I$ & -0.688 & -0.4219 & 1 & & 1 & \\
\hline $\ln$ Trad & 0.2492 & -0.4635 & 0.26017 & & 1 & \\
\hline Doll & 0.3749 & -0.5049 & 0.39172 & 0.38521 & & \\
\hline GDPP_1 & 0.4203 & 0.5920 & 0.2081 & 0.3109 & 0.3439 & 1 \\
\hline
\end{tabular}

Source: Own Compilation.

\subsection{Unit Root Test}

Unit root tests were performed using the Augmented Dickey Fuller (ADF) test and the results are indicated in Table 5. The results indicate that trade openness (lnTrade) is the only variable that is stationary in levels at a 1 percent level of significance. Interest rate $(\operatorname{lnI})$, Gross Domestic Investment (GDI) and lagged Gross Domestic Product per capita (GDP_1) are stationary after being differenced once and the probability values are significant at a 1 percent level. GDP is stationary after being differenced once but is weakly significant at a 10 percent level. Since all variables are either $\mathrm{I}(0)$ or $\mathrm{I}(1)$, it is possible to apply the ARDL procedure.

Table 5. Unit root test.

\begin{tabular}{ccccc}
\hline Variable & Probability & Variable & Probability & Order of Integration \\
\hline GDPP & 0.5260 & DGDPP & $0.0883^{*}$ & one \\
GDPP_1 & 0.2941 & DGDPP_1 & $4.166 \times 10^{-6 * * *}$ & one \\
Doll & 0.1397 & DDoll & $0.0418^{* *}$ & one \\
lnTrad & $0.0001^{* * *}$ & & & zero \\
GDI & 0.4931 & DGDI & $0.0000^{* * *}$ & one \\
lnI & 0.8676 & DINT & $1.447 \times 10^{-8 * * *}$ & one \\
\hline
\end{tabular}

\subsection{ARDL Cointegration Results}

Since the results of the unit root test indicate variables that are integrated at $1(0)$ and 1(1), a bound cointegration test was employed to check a long-run relationship between the variables. The results of 
the bound test are shown in Table 5. The results show an F statistic (5.961964) that is greater than the critical upper bound value (5.89). Therefore, the study rejects the null hypothesis of no cointegration and concludes that there is a long-run relationship that exists among these variables (Musoke 2017; Naceur et al. 2015).

As the outcomes of the Bound tests indicate a long-run relationship, the study analyses both the long-run and short-run relationship. The subsequent section presents the long-run analysis of the study. Thus, the long-run results are illustrated in Equation (3) and Table 6.

$$
\ln \mathrm{GDPP}_{t}=24.3369_{0}+\ln \mathrm{I}_{0.11_{t}}+\ln \operatorname{Trad} 1.13+\theta \text { Doll7.14 }+ \text { GDI } 2.04+\varepsilon_{t}
$$

Table 6. Auto Regressive Distributive Lag (ARDL) Cointegration Results.

\begin{tabular}{ccc}
\hline Test Statistic & Value & K \\
\hline F Statistic & 5.9620 & 3 \\
\hline \multicolumn{3}{c}{ Critical Value Bounds } \\
\hline \multicolumn{2}{c}{ Significance } \\
$10 \%$ & 3.01 & 4.71 \\
$5 \%$ & 3.76 & 4.94 \\
$2.5 \%$ & 3.90 & 4.99 \\
$1 \%$ & 4.81 & 5.89 \\
\hline
\end{tabular}

Source: Own compilation, 2019.

The prime and policy coefficient of dollarisation was found to be positive and statistically significant at 1 percent. This means the introduction of dollarisation increased the economic performance in Zimbabwe by 7.140458 units. The positive effect of dollarisation met apriori expectations as dollarisation brought with it economic stability and reduced inflation. The results are also in line with the study done by Musoke (2017) who argued that dollarisation leads to better economic performance in a developing country. GDI was found to positively impact the economic activities in the economy. GDI was, however, found to be weakly significant implying that the contribution of gross domestic investment to economic growth has not been high and the government has not been engaging much in public private partnerships to boost economic growth. The same results were found by Anderson (2016) who concluded that less can be done by domestic investors if the country is experiencing hyperinflation and high unemployment.

The trade openness coefficient was also found to be positive and statistically significant implying that trade increased the intensity of economic activity for the period under study. This is in agreement with the argument raised by Anderson (2016) and Mpofu (2015) who purported that dollarisation leads to real convergence in terms of GDPP levels and convergence of business cycles with the issuing country and that shocks also become more synchronized, further fostering integration. Contrary to popular reasoning that Zimbabwean imports have increased due to the depreciating South African rand over the period concerned, statistical results show that trade has been significantly positively contributing to economic growth in Zimbabwe.

Interest rates were found to be negatively related to economic growth because its coefficient is negative and statistically significant at a 1 percent level. This result was expected since the interest rates proxy considered was lending rates which measures the cost of borrowing. High lending rates have been cited to be one of the major variables negatively affecting investment levels in Zimbabwe. Previous year income per capita (GDPP_1) was found to be negative against the apriori expectation of a positive coefficient. This means the previous or lagged income per capita would reduce economic activities by less than the proportionate USD in the next economic year. This could be because the economy is declining due to the closure of firms and reduced capacity utilization (Confederation of Zimbabwe Industries (CZI) 2014). A negative value could also possibly be explained from the 
expectation's hypothesis. When the income from previous periods continues to decline, the expectation will be that it will continue to do so in the current period thereby leading to thrift behaviours that in turn negatively impact economic performance. Mankiw and Miron (1986) showed that coefficients are highly dependent on the period used for estimates and, as a general rule, observations and estimated parameters made during times of monetary tension are fairly unstable. The dollarisation era would be such a great scenario of a period of 'extreme' monetary tension. On the other hand, Hakkio and Rush (1989) highlighted that the omission of the expectation theory on links between interest rates, which should be specified in the form of an error-correction model and incorporates long-term link and short-term dynamics, could lead to specification biases.

The same Table 7 shows the results of the short-run analysis. The study found a -0.530918 speed of adjustment with the expected sign and significant at 1 percent. This implies that the 51 percent of the disequilibrium will be at equilibrium in the upcoming years.

Table 7. ARDL Long-run Results.

\begin{tabular}{ccccc}
\hline Variable & Coefficient & Std. Error & t-Statistic & Probability \\
\hline Doll & 7.1405 & 2.2161 & 3.5819 & $0.0038^{* * *}$ \\
I & -0.1108 & 0.0385 & -2.8814 & $0.0058^{* * *}$ \\
OPEN & 1.1336 & 0.3268 & 3.4687 & $0.0011^{* * *}$ \\
GDI & 2.0393 & 1.1257 & 1.8116 & $0.0761^{*}$ \\
GDPP_1 & -0.0482 & 0.0172 & -2.8011 & $0.0101^{* *}$ \\
C & 24.3369 & 6.7943 & 3.5819 & $0.0008^{* * *}$ \\
\hline \multicolumn{5}{c}{ ARDL SHORT-RUN RESULTS } \\
\hline ECM & -0.5309 & 1.7303 & -2.04028 & $0.0000^{* * *}$ \\
\hline
\end{tabular}

Source: Own computation, 2019. Note: ${ }^{* * *},{ }^{* *},{ }^{*}$ represents $1 \%, 5 \%$ \& $10 \%$ significance level, respectively.

\subsection{Post Estimation Results}

The diagnostic tests performed were: normality, heteroscedasticity and autocorrelation and the Ramsey RESET test of misspecification. As shown in Table 8 of estimated results, approximately 83 percent of the variations in economic growth are explained by combined variations in the regressors. This shows that the model is of good fit since more than half of the variations are explained within the model. Furthermore, the F-test probability value is 0.00023 implying that the whole model is valid at a 1 percent level of significance.

Table 8. Diagnostic Results.

\begin{tabular}{ccccccc}
\hline \multicolumn{3}{c}{ LM VERSION } & \multicolumn{3}{c}{ F VERSION } \\
\hline Test Statistic & Type & RS/Stats & $p$ Values & F-Dimension & F-Stats & $p$-Values \\
\hline $\begin{array}{c}\text { Serial Correlation: } \\
\text { Breusch-Godfrey }\end{array}$ & Chi-square (2) & 5.0541 & 0.1697 & 2.15 & 0.5002 & 0.7181 \\
\hline $\begin{array}{c}\text { Heteroscedasticity: } \\
\text { Breusch-Pagan Godfrey }\end{array}$ & Chi-square (9) & 22 & 0.3599 & 6,25 & 0.5436 & 0.7700 \\
\hline Normality of Residuals & Jarque-Bera & 2.602616 & 0.2722 & & & \\
\hline & & Source: Own computation.
\end{tabular}

The calculated Jacque-Bera statistic was found to be 2.602616 , while, the probability value was 0.272176 . This value is greater than 0.05 , hence the study concludes that the errors are normally distributed at a 5 percent level of significance. Having passed the normality assumption, the study concludes that Ordinary Least Square (OLS) estimators are not only Best Linear Unbiased Estimator (BLUE) but also follow well-known probability distributions. The OLS estimators of the intercept and slope are themselves normally distributed and the OLS estimator of the variance of the errors is related to the chi-squared distribution (Gujurati 2004). 
Using the Breusch-Pagan-Godfrey test, the results obtained strongly supported the null hypothesis that the errors are homoscedastic. The probability value of 0.7181 is less than the model's probability of 0.961 and this implies that we accept the null hypothesis and conclude that the errors are homoscedastic. Therefore, the results are reliable for interpretation. The Ramsey RESET Test confirms that the model is correctly specified as both the $\mathrm{F}$ and t probabilities are greater than 0.05 .

\section{Conclusions and Policy Recommendations}

In an attempt to alleviate Zimbabwean economic challenges, the monetary authorities introduced dollarisation. Thus, this study investigated whether dollarisation achieved its purpose by investigating its impact on economic growth from 2000 to 2015. To achieve this objective, this study employed an ARDL model that incorporates the bound test and the short-run analysis. The bound test confirmed a long-run relationship among the variables while long-run results indicate a positive relationship between economic growth and dollarisation. Furthermore, the short-run results show that the economy will converge in the upcoming year. Both the short-run and long-run results were affirmed by the diagnostic tests that attested to the absence of heteroscedasticity, auto-correlation and serial correlation.

Given the results and a careful study of existing literature, the study recommends, contrary to public reasoning, that the government should maintain the dollarisation stance due to the positive impact it has on economic growth in Zimbabwe. Dollarisation resulted in economic stability and improved credibility in the financial sector. These are key components for boosting investor confidence. However, policy makers should note that dollarisation on its own is not a cure but rather create the necessary environment for other policies to succeed. In other words, dollarisation creates the necessary but not sufficient environment for growth. Dollarisation mostly brings stability, improves credibility and promotes integration with anchor countries.

Despite this study achieving its objectives, it had a few limitations. Firstly, some variables were not considered due to unavailability of data, for instance, labour or employment data and diaspora remittances. The inflation variable was not included because inflation figures produced spurious results due to both the nature of the data and some missing figures of inflation during the crisis era. Secondly, the study focused on dollarisation from 2000 to 2015 and ignored other years after that. Therefore, this study can also be extended to include the post 2016 period to investigate the effects when the bond notes were introduced.

Author Contributions: Conceptualization, M.T.P.; methodology, M.T.P.; software, M.T.P.; validation, M.T.P. and R.G.; formal analysis, M.T.P.; investigation, R.G.; resources, M.T.P and R.G. data curation, M.T.P.; writing-original draft preparation, M.T.P.; writing—review and editing, M.T.P., R.G.; visualization, M.T.P.; supervision, M.T.P., R.G.; project administration, M.T.P and R.G.; funding acquisition, M.T.P and R.G. All authors have read and agreed to the published version of the manuscript.

Funding: This research received no external funding.

Conflicts of Interest: The authors declare no conflict of interest.

\section{References}

African Development Bank. 2014. Annual Reports. Available online: https://www.afdb.org/en/documentspublications/annual-report (accessed on 30 November 2019).

Anderson, Ariana. 2016. Dollarisation: A Case Study of Ecuador. Journal of Economics and Development Studies 5: $34-47$.

Aschinger, Gerhard. 2004. Currency Board, Dollarisation or Flexible Exchange Rates for Emerging Economies? Reflections on Argentina. Journal of Money, Credit and Banking 32: 34-45. [CrossRef]

Aslam, Salman. 1998. The Underground economy and Tax Evasion in Pakistan: Annual Estimates (1960-1998) and the Impact of Dollarisation of the Economy. The Pakistan Development Review 37: 621-31. [CrossRef]

Asteriou, Dimitrios, and Stephen Hall. 2007. Applied Econometrics: A Modern Approach. New York: Palgrave Macmillan. 
Bahmani-Oskooee, Mohsen, and Ilker Domaç. 2003. On the Link between Dollarisation and Inflation: Evidence from Turkey. Palgra Association for Comparative Economic Studies 45: 306-28. [CrossRef]

Barro, Robert J., and David B. Gordon. 1983. A positive theory of monetary policy in a natural rate model. Journal of Political Economy 91: 589-610. [CrossRef]

Berg, Andrew, and Eduardo Borensztein. 2000. The Pros and Cons of Full Dollarisation. International Monetary Fund Working Paper WP/00/50. Washington, DC: International Monetary Fund.

Bernanke, Ben S., and Ilian Mihov. 1998. Measuring Monetary Policy. The Quarterly Journal of Economics 113: 869-902. [CrossRef]

Calvo, Guillermo. 1999. Testimony on Full Dollarisation. Washington, DC: Economic Policy and International Trade and Finance.

Calvo, Guillermo. 2000. Fear of Floating. NBER Working Paper No 7993. Cambridge: National Bureau of Economic Research.

Calvo, Guillermo. 2001. Capital Markets and the Exchange Rate. Journal of Money, Credit and Banking 33: 312-34. [CrossRef]

Chang, Roberto, and Andres Velasco. 2002. Dollarisation: Analytical Issues. NBER Working Papers 8838. Cambridge: National Bureau of Economic Research.

Chigome, Jacob. 2011. What is the best currency regime for Zimbabwe. Geopolitics 7: 1-15.

Cohen, Benjamin. J. 2002. US Policy on Dollarisation: A political Analysis. Geopolitics 7: 63-84. [CrossRef]

Confederation of Zimbabwe Industries. 2014. Quarterly Digests. Available online: https://www.tradezimbabwe. com/priviledged-partners/confederation-of-zimbabwe-industries/ (accessed on 12 December 2019).

Corsetti, Giancarlo, and Paolo Pesenti. 2001. Welfare and Macroeconomic Interdependence. Quarterly Journal of Economics 116: 421-46. [CrossRef]

Corsetti, Giancarlo, and Paolo Pesenti. 2005. International Dimensions of Optimal Monetary Policy. Journal of Monetary Economics 52: 281-305. [CrossRef]

Dallas, Harris, and George S. Tavlas. 2001. Lessons of the euro for dollarisation: analytic and political economy perspectives. Journal of Policy Modelling 23: 333-45.

Devereux, Michael B., and Charles Engel. 2002. Monetary Policy in the Open Economy Revisited: Price Setting and Exchange Rate Flexibility. Review of Economic Studies 70: 765-83. [CrossRef]

Devereux, Michael Berka, and Charles Engel. 2003. Endogenous Exchange Rate Pass-through when Nominal Prices are Set in Advance. Journal of International Economics 63: 263-91. [CrossRef]

Edwards, Sebastian, and Igal Magendzo. 2001. Capital Flows and Economic Performance: Are Emerging Economies Different? NBER Working Paper Series 8076. Cambridge: National Bureau of Economic Research.

Eichengreen, Barry. 2000. Capital Account Liberalisation: What does Cross Country Studies Tell Us? World Bank Economics Review 15: 341-65. [CrossRef]

Fisher, Irving. 2001. The Stock Market Crash and After. New York: Macmillan Company.

Ford, Samuel. 2001. Dollarisation and the economy. Journal of Economics 9: 30-43.

Frankel, Jeffrey. 1999. No Single Currency Regime Is Right for All Countries or at All Times. NBER Working Paper 7338. Cambridge: National Bureau of Economic Research.

Frankel, Jefferey, and Andrew Rose. 2002. An Estimate of the Effect of Common Currencies on Trade and Income. The Quarterly Journal of Economics 117: 437-66. [CrossRef]

Friedman, Milton. 1953. The Methodology of Positive Economics. Essays on Positive 9: 157-203.

Girton, Lance, and Don Roper. 1977. A Monetary Model of Exchange Market Pressure Applied to the Postwar Canadian Experience. American Economic Review 67: 537-48.

Goldfajn, llan, and Gino Olivares. 2000. Is Adopting Full Dollarisation the Solution? Looking at the Evidence. Texto para discussáo, No. 416. Rio de Janeiro: Pontificia Universidade Católica do Rio de Janeiro (PUC-Rio), Departamento de Economica.

Government Budget. 2014. Towards an Empowered Society and a Growing Economy. Available online: https://www.dpcorp.co.zw/assets/2014-national-budget.pdf (accessed on 30 December 2019).

Grandes, Martin. 2001. External Solvency, Dollarisation and Investment Grade: Towards a Virtuous Circle? OECD Development Center Working Paper No. 177. Paris: OECD Publishing.

Gujurati, Damodar N. 2004. Basic Econometric, 4th ed. New York: The McGraw-Hill Companies.

Hakkio, Craig, and Mark Rush. 1989. Market Efficiency and Cointegration: An Application to the Sterling and Deutschmark Exchange Markets. Journal of International Money and Finance 8: 75-88. [CrossRef] 
Hanke, Steve H., and Kwok F. Alex. 2009. On the Measurement of Zimbabwe's Hyperinflation. The Cato Journal 20: 56-79.

Hausmann, Ricardo, Dani Rodrik, and Andrés Velasco. 2006. Getting the Diagnosis Right. Finance and Development 43: 12-15.

Havrylyshyn, Oleh, and Christian H. Beddies. 2003. Dollarisation in the former Soviet Union: From Hysteria to Hysteresis. Comparative Economic Studies 45: 329-58. [CrossRef]

Ize, Alain, and Eduardo Levy Parratoi. 2005. Financial De-Dollarisation: Is It for Real? International Monetary Fund Working Paper 187. Washington, DC: International Monetary Fund.

Johnson, Harry G. 1972. The Case for Flexible Exchange Rates. Further Essays in Monetary Economics. Cambridge: Harvard University Press.

Kanyenze, Godfey, Prosper Chitambara, and Judith Tyson. 2017. The Outlook of the Zimbabwean Economy. Available online: https://www.odi.org/publications/10921-outlook-zimbabwean-economy (accessed on 1 November 2019).

Krugman, Paul R. 1990. Rethinking International Trade. Cambridge: MIT Press.

Lakić, Slobodan, Damir Šehović, and Jasmina Ćetković. 2016. An analysis of the official dollarisation regime in Montenegro: theoretical approaches and empirical evidence. Journal of International Studies 9: 48-64. [CrossRef] [PubMed]

Linsman, Johannes Hubertus Cornelius, and Jan Sandee. 1964. Derivation of quarterly figures from annual data. Applied Statistics 13: 87-90. [CrossRef]

Makochekanwa, Alfr. 2009. Zimbabwe Currency's Crisis: Which Currency to Adopt Aftermath Multi-Currency Regime? MPRA, Paper 22463. Munich: Munich Personal RePEc Archive.

Makoto, Richard. 2012. Dollarisation and the way forward in Zimbabwe. Journal of Strategic Studies 12: 51-67.

Mankiw, N. Gregory, and Jeffrey A. Miron. 1986. The Changing Behavior of the Term Structure of Interest Rates. The Quarterly Journal of Economics 101: 211-28. [CrossRef]

McKinnon, Ronald. I. 1982. Currency Substitution and Instability in the World Dollar Standard. American Economic Review 3: 320-33.

Miles, Robert. 1978. Dollarisation. New York: McGraw-Hill.

Mohapatra, Geetilaxmi, Akgiri K. Giri, and Madhu Sehrawat. 2016. Foreign aid, macroeconomic policies and economic growth nexus in India: An ARDL bounds testing approach. Theoretical and Applied Economics 23: 183-202.

Molano, Walter. 2000. Argentina: The No Brainer Danger of Devaluation. New York: BCP.

Moron, Eduardo, and Juan F. Castro. 2003. De-dollarising the Peruvian economy: A Portfolio Approach. Journal of Economics 23: 12-23.

Mpofu, Raphael Tabani. 2015. Dollarisation and economic development: An interrupted time-series analysis. Risk Governance \& Control: Financial Markets E Institutions 5: 52-62.

Mundell, Robert. 1973. Uncommon Arguments for Common currencies: The Economics of Common currencies. Paper presented at the Madrid Conference on Optimum Currency Areas, Madrid, Spain, March 19.

Musoke, Zakia. 2017. An Empirical Investigation on Dollarisation and Currency Devaluation: A Case Study of Tanzania. Economics Discussion Papers. Keil: Kiel Institute.

Naceur, Ben S., Amr Hosny, and Gregory Hadjian. 2015. How to De-Dollarise Financial Systems in the Caucasus and Central Asia? International Monetary Fund Working Paper 203 IMF. Munich: University Library of Munich.

Ncanywa, Thobeka, and Kabelo Mabusela. 2018. Can financial development influence economic growth: The Sub-Saharan analysis? Journal of Economic and Financial Sciences 12: 20-32. [CrossRef]

Nkomazana, Lionel, and Ferdinand Niyimbanira. 2014. An Overview of the Economic Causes and Effects of Dollarisation: Case of Zimbabwe. Mediterranean Journal of Social Sciences 5: 69-73. [CrossRef]

Panteleo, Peter. 2011. Dollarisation in Tanzania: Empirical Evidence and cross Country Experience. Dar es Salaam: Bank of Tanzania.

Pesaran, M. Hashem, and Yongcheol Shin. 1999. An Autoregressive Distributed Lag Modelling Approach to Co-Integration. Cambridge: Cambridge University Press.

Price WaterHouse Coopers. 2018. Money Is No Object: Understanding the Evolving Cryptocurrency Market. Available online: https://bravenewcoin.com/assets/Industry-Reports-201d/pwc-cryptocurrency-evolution. pdf (accessed on 4 November 2019). 
Quispe, Zenon. 2000. Transmission mechanisms of monetary policy in an economy with partial dollarisation: The case of Peru. BIS Papers Chapters. In Modelling Aspects of the Inflation Process and the Monetary Transmission Mechanism in Emerging Market Countries. Edited by Bank for International Settlements. Lima: Bank for International Settlements, vol. 8, pp. 210-31.

Quispe Misaico, Zenón. 2000. Política monetaria en una economía con dolarización parcial: El caso del Perú. Revista Estudios Económicos, Banco Central de Reserva del Perú 6: 10-29.

Reserve Bank of Zimbabwe. 2016. Monetary Policy Statement. Available online: https://www.rbz.co.zw/ documents/mps/mpsjuly2016.pdf (accessed on 1 December 2019).

Reserve Bank of Zimbabwe. 2018. Monetary Policy Statement. Available online: https://www.rbz.co.zw/ documents/mps/mpsjuly2018.pdf (accessed on 25 November 2019).

Rose, Andrew, and Charles Engel. 2000. Currency Unions and International Integration. NBER Working Paper 7872. Cambridge: National Bureau of Economic Research.

Sikwila, Mike Nyamazana. 2013. Dollarisation and the Zimbabwe's Economy. Journal of Economics and Behavioral Studies 5: 398-405. [CrossRef]

Sosic, Vedran, and Micheal Faulend. 2002. Dollarisation and the Underground Economy: Accidental Parteners. Occasional Paper Series 15. Zagreb: Institute of Public Finance.

Summers, Lawrence. 2001. US economic prospects: Secular stagnation, hysteresis, and the zero lower bound. Business Economics 49: 65-73. [CrossRef]

Tanzi, Vito. 1983. The Underground Economy in the United States: Annual Estimates (1930-80). International Monetary Fund Staff Papers. Oxford: University of Oxford, pp. 283-305.

Winkler, A., Francesco Mazzaferro, Carolin Nerlich, and Christian Thimman. 2004. Official Dollarisation/Euroisation: Motives, Features and Policy Implications of Current Cases. Paper 11. Frankfurt: European Central Bank.

World Bank. 2015. Maintaining High Growth. Cambodia Economic Update April 2015. Phnom Penh: World Bank.

Zimbabwe Revenue Authority. 2019. Dollarisation and the Economy. Available online: https://www.zimra.co.zw/ (accessed on 20 November 2019).

(C) 2020 by the authors. Licensee MDPI, Basel, Switzerland. This article is an open access article distributed under the terms and conditions of the Creative Commons Attribution (CC BY) license (http://creativecommons.org/licenses/by/4.0/). 